Acta Universitatis Wratislaviensis No 3798

DOI: $10.19195 / 0524-4544.323 .23$

\author{
WITOLD MAŁECKI \\ Uniwersytet Wrocławski \\ e-mail: witold.malecki@uwr.edu.pl
}

\title{
Metoda promocji jako typ metody regulacji
}

\section{Metoda regulacji i jej komponenty}

Pojęcie metody regulacji na gruncie polskiej nauki zdaje się występować jako pojęcie-narzędzie ${ }^{1}$, wykorzystywane na szeroką skalę w rozważaniach nad podziałem systemu prawa w strukturze poziomej - jest wszak metodą regulacji uznawana za wiodące, obok przedmiotu regulacji, kryterium wyodrębniania gałęzi prawa ${ }^{2}$. Instrumentalna perspektywa postrzegania metody regulacji wydaje się wyrażać w posługiwaniu się kategorią metody regulacji wyłącznie na płaszczyźnie szczegółowej w odniesieniu do poszczególnych gałęzi prawa (np. metoda regulacji prawa administracyjnego, metoda regulacji prawa cywilnego), z pominięciem refleksji nad istotą i wyznacznikami metody regulacji w ogólności ${ }^{3}$.

${ }^{1}$ O pojęciach-narzędziach i pojęciach-przedmiotach zob. F. Longchamps, Uwagi o używaniu pojęć w naukach prawnych, „Zeszyty Naukowe Uniwersytetu Wrocławskiego. Prawo” 7, 1960, s. $11-12$.

2 Por. m.in. A. Stelmachowski, Wstęp do teorii prawa cywilnego, Warszawa 1969, s. 17; W. Lang, J. Wróblewski, S. Zawadzki, Teoria państwa i prawa, Warszawa 1986, s. 410; K. Pleszka, T. Gizbert-Studnicki, Obraz systemu prawa w dogmatyce prawniczej, [w:] Szkice z teorii prawa i szczegółowych nauk prawnych, red. S. Wronkowska, Z. Ziembiński, Poznań 1990, s. 162; S. Wronkowska, Podstawowe pojęcia prawa i prawoznawstwa, Poznań 2005, s. 114; A. Bator, [w:] Wprowadzenie do nauk prawnych. Leksykon tematyczny, red. A. Bator, Warszawa 2008, s. 157-158; H. Izdebski, Elementy teorii i filozofii prawa, Warszawa 2011, s. 240-243.

3 Jedną z nielicznych w polskiej nauce prawa definicji metody regulacji w ogólności sformułował Stanisław Włodyka, wskazując, że metoda regulacji to „podporządkowana pewnym założeniom ogólnym świadoma działalność ustawodawcy polegająca na wyborze takich, a nie innych form wprowadzania w życie pewnych zasad postępowania (norm prawnych)" - idem, Problem „prawa gospodarczego", „Studia Cywilistyczne” 5, 1964, s. 126. 
Znacznie więcej uwagi poświęcono pojęciu metody regulacji w nauce radzieckiej i rosyjskiej ${ }^{4}$. Nie uchybiając instrumentalnej doniosłości metody regulacji i jej znaczeniu dla wyodrębniania w systemie prawa gałęzi, badacze ci podejmowali refleksję nad metodą regulacji w ogólności, tj. nad metodyką wpływania przez prawodawcę na stosunki społeczne za pomocą celowo kształtowanych norm prawnych. Dualizm perspektyw postrzegania metody regulacji wyraził Władimir S. Biełych, wyróżniając metodę regulacji w rozumieniu szerokim i wąskim (choć bardziej adekwatne — jak się wydaje — byłyby określenia in abstracto i in concreto). W rozumieniu szerokim (in abstracto) metoda regulacji obejmuje dwa zasadnicze sposoby wpływania przez ustawodawcę na stosunki społeczne - imperatywną metodę regulacji (w przypadku której norma prawna autorytatywnie wyznacza treść stosunku prawnego) i dyspozytywną metodę regulacji (tu norma prawna ma na celu kształtowanie stosunków społecznych w sposób niewładczy) ${ }^{5}$. W rozumieniu wąskim (in concreto) metoda regulacji podlega relatywizacji $\mathrm{w}$ odniesieniu do poszczególnych gałęzi prawa, przyjmując postać konglomeratu metody imperatywnej i metody dyspozytywnej, których proporcje i postać szczegółowa są warunkowane specyfiką danej gałęzi prawa ${ }^{6}$. Albowiem, jak trafnie zaznacza Jurij K. Tołstoj, współcześnie nie istnieją „chemicznie czyste" gałęzie prawa, w których choćby w niewielkim stopniu nie występowała każda $\mathrm{z}$ obu zasadniczych metod regulacji ${ }^{7}$.

$\mathrm{Z}$ polskiej perspektywy druga $\mathrm{z}$ metod regulacji $\mathrm{w}$ rozumieniu szerokim (in abstracto) — metoda dyspozytywna — wywołuje a priori skojarzenie z normami iuris dispositivi, tj. normami względnie stosowanymi, „mającymi zastosowanie wtedy, gdy ich potencjalni adresaci nie uregulują danego stosunku inaczej, aniżeli to wynika z przepisu formułującego tego rodzaju normę" ${ }^{8}$, typowo występującymi w obrębie prawa cywilnego. W nauce rosyjskiej metoda dyspozytywna obejmuje wszelako katalog instrumentów prawnych szerszy niż li tylko normy iuris dispositivi — jak wskazuje Swietłana W. Polienina, zastosowanie metody dyspozytywnej daje adresatom norm prawnych możliwość wyboru, w granicach prawa, alternatywnych wzorów zachowań innych niż wskazane w normach prawnych ${ }^{9}$, czego konsekwencje mogą być zróżnicowane.

${ }^{4}$ W Związku Radzieckim metoda regulacji stała się przedmiotem zainteresowania nauki w rezultacie dyskusji nad systemem prawa i jego strukturą, zapoczątkowanej po XX Zjeździe KPZR w 1956 r. - por. m.in. I.W. Pawłow, O sistiemie sowietskogo socialisticzeskogo prawa, „Sowietskoje Gosudarstwo i Prawo" 1958, nr 11, s. 7.

5 W.S. Biełych, Prawowoje riegulirowanije priedprinimatielskoj diejatielnosti w Rossii, Moskwa 2005, s. 65.

${ }^{6}$ Ibidem, s. 65-66.

7 J.K. Tołstoj, O priepodowanii grażdanskogo prawa na sowriemiennom etapie, [w:] Priepodowanie grażdanskogo prawa w sowriemiennych usłowiach, red. J.K. Tołstoj, Sankt Petersburg 1999, s. 43.

8 S. Kaźmierczyk, [w:] Wprowadzenie do nauk prawnych..., s. 87.

9 S.W. Polienina, [w:] Tieorija gosudarstwa i prawa, red. W.K. Babajew, Moskwa 2003, s. 392. 
Inspirując się stanowiskami formułowanymi w nauce rosyjskiej, na podstawie kryterium prawnych następstw odrzucenia przez adresata normy prawnej wzoru zachowania wyznaczonego w normie, w obrębie dyspozytywnej metody regulacji wypada wyróżnić trzy metody szczegółowe: metodę dyspozytywną sensu stricto, metodę promocji i metodę rekomendacji. Metoda dyspozytywna sensu stricto opierałaby się zatem na wykorzystaniu norm iuris dispositivi w rozumieniu przytoczonym powyżej — w rezultacie odrzucenia przez adresata normy prawnej wzoru zachowania w niej zawartego moc wiążącą uzyskuje wzór zachowania stworzony przez adresata. Metoda promocji polega na posługiwaniu się przez ustawodawcę normami promującymi (pooszczritielnyje normy), tj. — według Władimira K. Babajewa - normami ,ustanawiającymi pewne bodźce zachęty, korzyści w zamian za wybranie przez adresata normy wariantu postępowania pożądanego z perspektywy państwa lub społeczeństwa"10. Skutkiem niezastosowania się adresata normy promującej do wzoru zachowania ustanowionego w niej, polegającego na podjęciu postępowania niezakazanego przez prawo, lecz pozbawionego społecznej doniosłości, będzie zatem wyłączenie możliwości uzyskania korzyści przewidzianych z tytułu realizacji pożądanego i promowanego przez ustawodawcę wzoru zachowania. Ostatnia z metod szczegółowych — komponentów dyspozytywnej metody regulacji, tj. metoda rekomendacji, zasadza się na wykorzystaniu norm rekomendujących (riekomiendatielnyje normy), które „ustanawiają warianty najbardziej pożądanego z punktu widzenia państwa uregulowania stosunków społecznych"11, bez określenia w żaden sposób konsekwencji niezastosowania się do normy. Normy rekomendujące stanowią więc niewiążące wytyczne, sugestie formułowane przez ustawodawcę, których odrzucenie nie powoduje dla adresata normy żadnych skutków prawnych ${ }^{12}$.

Na gruncie ustawodawstwa polskiego kumulatywne zastosowanie przez ustawodawcę wszystkich trzech metod szczegółowych, kreujących dyspozytywną metodę regulacji, stanowi cechę znamienną metody regulacji prawa gospodarczego. Normy iuris dispositivi występują w prywatnoprawnej części prawa gospodarczego, odnosząc się do zagadnień ustroju i funkcjonowania podmiotów gospodarczych ${ }^{13}$, a także treści umów, których zastosowanie zostało normatyw-

10 W.K. Babajew, [w:] Tieorija gosudarstwa i prawa, s. 379.

11 Ibidem.

12 Wypada zaznaczyć, że w wypadku z jednej strony norm iuris dispositivi oraz norm promujących i norm rekomendujących z drugiej odmienną postać przybiera sposób odrzucenia niewiążącego wzoru zachowania wynikającego $\mathrm{z}$ normy. $\mathrm{W}$ odniesieniu do norm iuris dispositivi odrzucenie wzoru zachowania ma charakter aprioryczny, poprzez uprzednie rozstrzygnięcie, że adresat normy nie będzie jej realizował i w miejsce wzoru zachowania zawartego w normie ustanowi samodzielnie, w granicach prawa, odmienny wzór zachowania, odpowiadający jego potrzebom. W przypadku norm promujących i rekomendujących odrzucenie wzoru zachowania zawartego w normie ma charakter aposterioryczny i realizuje się poprzez proste podjęcie postępowania odmiennego niż wskazane w normie.

13 Por. m.in. art. $37 \S 1$, art. $176 \S 3$, art. $337 \S 3$ Kodeksu spółek handlowych oraz art. $17 \S 3$ Prawa spółdzielczego. 
nie ograniczone do sfery obrotu gospodarczego ${ }^{14}$. Normy rekomendujące występują $\mathrm{w}$ zasadniczej mierze $\mathrm{w}$ przepisach rozporządzeń o charakterze policyjnym, obejmując sugestie ustawodawcy $\mathrm{w}$ zakresie sposobu wywiązywania się przedsiębiorców z nałożonych na nich przepisami ustaw powinności w zakresie ochrony stanów i dóbr policyjnych przed zagrożeniami wynikającymi z wykonywania działalności gospodarczej ${ }^{15}$. Również w przypadku metody promocji norm stanowiących ucieleśnienie jej zastosowania przez ustawodawcę należy doszukiwać się $\mathrm{w}$ obrębie regulacji prawa gospodarczego - w niniejszym opracowaniu przykłady tego rodzaju norm zostaną poddane zwięzłej analizie dogmatycznej i teoretycznej.

\section{Zastosowanie metody promocji w obrębie regulacji prawa gospodarczego}

Zgodnie z przywołaną definicją norm promujących W.K. Babajewa normy te zakładają wykorzystanie przez prawodawcę bodźców zachęty dla adresatów normy, którzy zrealizują wskazany w niej, doniosły społecznie, wzór zachowania. Przedmiotowe bodźce zachęty przybierają na gruncie polskiego prawodawstwa, w obrębie regulacji prawa gospodarczego, różnorodne postaci. Niewątpliwie szczególnie atrakcyjny dla adresatów norm-przedsiębiorców bodziec zachęty stanowią korzyści finansowe, które mogą realizować się zarówno jako świadczenia pieniężne na rzecz przedsiębiorców stosujących się do pożądanych wzorów zachowań, jak i redukcja spoczywających na przedsiębiorcach obciążeń publicznoprawnych.

Normę ujmującą jako bodziec zachęty świadczenia pieniężne można wywodzić przykładowo z regulacji § 20e Rozporządzenia Ministra Gospodarki z dnia 2 grudnia 2006 r. w sprawie udzielania przez Polską Agencję Rozwoju Przedsiębiorczości pomocy finansowej niezwiązanej z programami operacyjnymi ${ }^{16}$, wydanego na podstawie upoważnienia zawartego w art. $6 \mathrm{~b}$ ust. 11 Ustawy z dnia 9 listopada 2000 r. o utworzeniu Polskiej Agencji Rozwoju Przedsiębiorczości ${ }^{17}$. Promowany wzór zachowania, adresowany do mikroprzedsiębiorców, małych i średnich przedsiębiorców, mających siedzibę lub miejsce zamieszkania na terytorium Rzeczypospolitej Polskiej, stanowi — zgodnie z § 20e ust. 7 pkt 2 rozpo-

14 Por. m.in. art. $761^{7} \S 1$ i art. $827 \S 3$ Kodeksu cywilnego.

15 Por. m.in. ust. 3.2 oraz 3.6 w części I załącznika nr 2 do Rozporządzenia Ministra Gospodarki z dnia 17 czerwca 2002 r. w sprawie bezpieczeństwa i higieny pracy, prowadzenia ruchu oraz specjalistycznego zabezpieczenia przeciwpożarowego w odkrywkowych zakładach górniczych wydobywających kopaliny podstawowe (Dz.U. Nr 99, poz. 858 ze zm.); ust. 7.12 pkt 4 w części I załącznika do Rozporządzenia Ministra Gospodarki z dnia 4 maja 2007 r. w sprawie szczegółowych warunków funkcjonowania systemu elektroenergetycznego (Dz.U. Nr 93, poz. 623 ze zm.).

16 Dz.U. Nr 226, poz. 1651 ze zm.

17 Dz.U. z 2016 r. poz. 359. 
rządzenia - przygotowanie i złożenie wniosku projektowego w odpowiedzi na wezwanie konkursowe w ramach międzynarodowego programu innowacyjnego. Nie wydaje się budzić wątpliwości, że podejmowanie działalności innowacyjnej, jakkolwiek wymagające poniesienia przez przedsiębiorcę nakładów i inwestycji, wiąże się z perspektywą pozytywnych skutków zarówno dla przedsiębiorcy, jak i gospodarki narodowej, co uzasadnia wsparcie państwa dla tego kierunku działalności ${ }^{18}$. Przedsiębiorca, który podejmie promowane zachowanie, jest uprawniony do ubiegania się — na podstawie $\S 20$ e ust. 1 rozporządzenia - o bezzwrotne wsparcie finansowe, przeznaczone na pokrycie kosztów przygotowania i złożenia jednego wniosku projektowego, w odpowiedzi na jedno wezwanie konkursowe, w ramach międzynarodowego programu innowacyjnego, którego realizacja rozpoczęła się nie wcześniej niż w 2007 r.

Korzyści finansowe ustanawiane przez prawodawcę z tytułu realizowania promowanych wzorów zachowania, jak zasygnalizowano, mogą przyjmować również postać redukcji obciążeń publicznoprawnych spoczywających na przedsiębiorcach. Tego rodzaju korzyść finansową przewidział prawodawca w Ustawie z dnia 27 sierpnia 1997 r. o rehabilitacji zawodowej i społecznej oraz zatrudnianiu osób niepełnosprawnych ${ }^{19}$, której przepisy realizują wynikający z art. 69 Konstytucji imperatyw udzielania przez władze publiczne pomocy osobom niepełnosprawnym w zabezpieczaniu egzystencji, przysposobieniu do pracy oraz komunikacji społecznej. W związku z istotnym znaczeniem społecznym integracji osób niepełnosprawnych, urzeczywistnianej m.in. poprzez ich uczestnictwo w środowiskach pracy, norma promująca - wywodzona z art. 28 ust. 1 pkt 1 lit. b powołanej ustawy - obejmuje wzór zachowania nakierowany na zwiększenie stopnia zatrudnienia osób niepełnosprawnych. Wzór zachowania adresowany jest do ,pracodawców prowadzących działalność gospodarczą przez okres co najmniej 12 miesięcy, zatrudniających nie mniej niż 25 pracowników w przeliczeniu na pełny wymiar czasu pracy” i ma za przedmiot zatrudnianie „,co najmniej 30\% niewidomych lub psychicznie chorych albo upośledzonych umysłowo zaliczonych do znacznego albo umiarkowanego stopnia niepełnosprawności” (por. art. 28).

Pracodawcy, którzy realizują wskazany wzór zachowania (oraz spełniają wymogi określone w art. 28 ust. 1 pkt 2-4 ustawy), mogą ubiegać się o przyznanie im statusu pracodawcy prowadzącego zakład pracy chronionej, w następstwie czego upoważnieni są do skorzystania ze zwolnienia ustanowionego w art. 31 ustawy — zgodnie z przepisem tym zwolnienie obejmuje wszystkie podatki i opłaty, z wyjątkiem podatku od gier, podatku od towarów i usług, podatku akcyzowego, podatków dochodowych, podatku od środków transportowych, cła, opłaty skarbo-

18 Zgodnie z art. 4 ust. 4 pkt 2 ustawy o utworzeniu Polskiej Agencji Rozwoju Przedsiębiorczości wspieranie i promocja przedsięwzięć w zakresie rozwoju innowacyjności należy do zadań Agencji.

19 Dz.U. z 2016 r. poz. 2046 ze zm. 
wej i opłat o charakterze sankcyjnym ${ }^{20}$. Na podstawie art. 31 ust. 3 ustawy środki finansowe, które pracodawca-przedsiębiorca uzyskał z tytułu opisanego zwolnienia, podlegają przeznaczeniu na zakładowy fundusz rehabilitacji osób niepełnosprawnych (w 90\%) oraz Państwowy Fundusz Rehabilitacji Osób Niepełnosprawnych (w $10 \%$ ). Środki uzyskane z tytułu zwolnienia w $90 \%$ pozostają więc w dyspozycji pracodawcy, który powinien przeznaczyć je, w ramach zakładowego funduszu rehabilitacji osób niepełnosprawnych, na finansowanie rehabilitacji zawodowej, społecznej i leczniczej osób niepełnosprawnych oraz ubezpieczenie osób niepełnosprawnych — zgodnie z art. 33 ust. 4 ustawy. Zasilanie funduszu środkami uzyskanymi z tytułu zwolnienia - o ile pozwala na efektywną realizację powołanych celów - może uwolnić pracodawcę-przedsiębiorcę od konieczności przeznaczania na fundusz kwot pieniężnych z innych źródeł, powiększając jego zysk związany z wykonywaniem działalności gospodarczej ${ }^{21}$.

Przewidziane w polskim ustawodawstwie korzyści z tytułu realizacji przez przedsiębiorców promowanych wzorów zachowań mogą przybierać również postać inną niż finansowa. Przykład normy promującej związanej z korzyścią o charakterze niefinansowym można odnaleźć w regulacjach Ustawy z dnia 29 stycznia 2004 r. - Prawo zamówień publicznych ${ }^{22}$. Artykuł 22 ust. 2 tej ustawy wyznacza promowany wzór zachowania, polegający na prowadzeniu działalności obejmującej „,społeczną i zawodową integrację osób będących członkami grup społecznie marginalizowanych", w szczególności zaś osób niepełnosprawnych, bezrobotnych czy z zaburzeniami psychicznymi. Korzyść przewidzianą dla podmiotów realizujących wskazany wzór zachowania może stanowić prawo ubiegania się o udzielenie zamówienia publicznego - w sytuacji gdy zamawiający, działając na podstawie art. 22 ust. 2 Prawa zamówień publicznych, zastrzegł w ogłoszeniu o zamówieniu, że o udzielenie zamówienia mogą ubiegać się wyłącznie wykonawcy prowadzący wskazany rodzaj działalności.

Wypada zaznaczyć, że ucieleśniająca normę promującą regulacja art. 22 ust. 2 Prawa zamówień publicznych stanowi świadectwo implementacji do polskiego porządku prawnego instytucji zamówień zastrzeżonych, ustanowionej w art. 20

20 Ponadto w przypadku podatków od nieruchomości, rolnego i leśnego zwolnienie następuje na zasadach określonych w przepisach odrębnych, zaś w wypadku podatku od czynności cywilnoprawnych prowadzący zakład pracy chronionej jest zwolniony z podatku, jeżeli „czynność przez niego dokonana pozostaje w bezpośrednim związku z prowadzeniem zakładu”. Warto zaznaczyć, że Naczelny Sąd Administracyjny w wyroku z dnia 12 października 2012 r. (sygn. II FSK 474/11, http://orzeczenia.nsa.gov.pl, dostęp: 14.11.2017) stwierdził, że zwolnienie przewidziane w art. 31 ust. 1 pkt 1 cytowanej ustawy ,nie jest zwolnieniem podmiotowym o charakterze generalnym, lecz zwolnieniem o charakterze podmiotowo-przedmiotowym, a podatnik ma obowiązek wykazać, iż posiada status prowadzącego zakład pracy chronionej oraz że istnieje związek pomiędzy przedmiotem opodatkowania a działalnością gospodarczą prowadzonego zakładu pracy chronionej”.

21 Zgodnie z art. 33 ust. 1 ustawy prowadzący zakład pracy chronionej jest zobowiązany do utworzenia zakładowego funduszu rehabilitacji osób niepełnosprawnych.

22 Dz.U. z 2017 r. poz. 1579 ze zm. 
ust. 1 Dyrektywy 2014/24/UE Parlamentu Europejskiego i Rady z dnia 26 lutego 2014 r. w sprawie zamówień publicznych, uchylającej dyrektywę 2004/18/ $\mathrm{WE}^{23}$. Wydaje się, że instytucję zamówień zastrzeżonych należy postrzegać jako odzwierciedlenie w unijnym porządku prawnym koncepcji społecznie odpowiedzialnych zamówień publicznych, które mają służyć „uwzględnianiu przez zamawiających różnych aspektów społecznych, np. możliwości zatrudnienia i godnej pracy, integracji społecznej, wyrównywania szans", co sprzyjać ma powstawaniu „rynków świadomych społecznie"24.

\section{Uwagi teoretyczne}

Metoda promocji, jak zaznaczano w powyższych rozważaniach, zasadza się na ustanawianiu przez prawodawcę norm promujących. Wypada jednakże podkreslić, że trafność posługiwania się pojęciem „norm promujących” nie przedstawia się jako zagadnienie w pełni jednoznaczne z uwagi na nieprzystawalność desygnatów nazwy „norma promująca”, w kształcie przedstawionym w części drugiej niniejszego opracowania, do denotacji nadrzędnej nazwy „norma prawna" w ujęciu prezentowanym przez niektórych autorów. Szeroko rozpowszechnione $\mathrm{w}$ literaturze jest bowiem postrzeganie normy prawnej na płaszczyźnie ultymatywnej jako kwalifikowanej postaci normy postępowania, znamionowanej elementem powinności - nakazem lub zakazem określonego zachowania, czego wyrazem są m.in. stanowiska Henryka Rota ${ }^{25}$ i Sławomiry Wronkowskiej ${ }^{26}$.

Wobec kategorii ujmowanych w sposób ultymatywny norm prawnych normy promujące wydają się a priori nieprzystawalne. Ze swej istoty obejmują one bowiem wzory zachowań nienacechowane doniosłością społeczną w stopniu wystarczającym, by wymuszać na przedsiębiorcach ich realizację za pomocą nakazów i zakazów - celem norm promujących jest kształtowanie u przedsiębiorców pozytywnych postaw społecznych, których realizacja, choć dodatnio wartościowana moralnie, nie warunkuje bezpiecznego i zgodnego z prawem funkcjonowania obrotu gospodarczego. Normy promujące niewątpliwie wypada zaliczyć do nadrzędnej wobec norm prawnych kategorii wypowiedzi dyrektywnych (analizowanych szeroko przez Kazimierza Opałka), których treść obejmuje dwa elementy

23 Dz. Urz. UE L 94 z 28 marca 2014 r. z późn. zm., s. 65.

24 M. Olszewska, Klauzule społeczne w zamówieniach publicznych, „Monitor Zamówień Publicznych" 2016, nr 10, s. 19.

${ }^{25}$ H. Rot definiuje normę postępowania jako ,wyrażenie jakiegoś języka, przez które bezpośrednio wskazuje się komuś, jak powinien jednorazowo postąpić czy też stale postępować w określonych okolicznościach" - idem, Wstęp do nauk prawnych, Wrocław 1998, s. 27.

26 Według S. Wronkowskiej norma postępowania to „wypowiedź, która określonym podmiotom jako jej adresatom nakazuje albo zakazuje, aby w określonych okolicznościach postąpiły albo postępowały w określony sposób" - eadem, op. cit., s. 13. 
— wzór zachowania i operator dyrektywny, mogący przybierać różnorodne postaci, jak np. ,jest życzone”, „radzi się”, „zaleca się”, „,nakłania się”, ,jest obowiązkowe", ,jest zakazane"27. Spośród wskazanych operatorów w normach promujących operator dyrektywny - wywodzony z treści relewantnych przepisów prawnych, choć niewysłowiony w nich explicite - mógłby przedstawiać się jako „nakłania się" lub ,zaleca się”.

Cechą znamienną normy promującej jest wszelako możliwość transformacji operatora dyrektywnego towarzyszącego zawartemu w normie wzorowi zachowania. Powiązanie normy promującej, tj. wzoru zachowania opatrzonego nieultymatywnym operatorem dyrektywnym, $\mathrm{z}$ bodźcem zachęty przewidzianym $\mathrm{z}$ tytułu jej realizacji ustawodawca osiąga za pomocą konstrukcji dyrektywy celowościowej, tzn. „wyrażenia, które głosi, co należy czynić, aby osiągnąć zamierzony skutek"28, osiągającego kształt: ,jeśli chcesz osiągnąć cel C, to powinieneś zachować się w sposób $\mathrm{S}^{\text {"29 }}$. W ramach struktury dyrektywy celowościowej - i tylko w ramach tej struktury - wzór zachowania zaczerpnięty z normy promującej podlega powiązaniu z operatorem ,jest nakazane”, przybierając postać zakresu normowania dyrektywy celowościowej (,,powinieneś zachować się w sposób S”). Ujęcie w postaci nakazu wzoru zachowania zawartego w normie promującej jest zatem ściśle ograniczone do kontekstu związanego z ubieganiem się przez adresata normy promującej o uzyskanie korzyści wskazanej w zakresie zastosowania dyrektywy celowościowej (,jeśli chcesz osiągnąc cel C”). Reasumując, wzór zachowania objęty treścią normy promującej jest co do zasady nieobowiązkowy i jedynie zalecany adresatom normy, z wyjątkiem sytuacji, w której adresat normy dąży do osiągnięcia korzyści opisanej w zakresie zastosowania dyrektywy celowościowej, której zakres normowania zawiera wzór zachowania danej normy promującej. Wydaje się więc, że z uwagi na potencjał ultymatywny norm promujących można uznać za uzasadnione zaliczanie ich do kategorii norm prawnych.

Wypada zaznaczyć, że w zbiorze dyrektyw celowościowych dyrektywy związane $\mathrm{z}$ normami promującymi odznaczają się pozytywnym nacechowaniem $\mathrm{z}$ perspektywy wartości chronionych w systemie prawa - wzorów zachowań zawartych w zakresach normowania dyrektyw. W przypadku licznych dyrektyw celowościowych zachowania objęte treścią ich zakresów normowania pozbawione są oceny moralnej — przykładowo: ,jeżeli chcesz w sposób ważny przyjąć lub odrzucić spadek, złóż oświadczenie przed sądem lub przez notariuszem”, ,jeżeli chcesz uzyskać wpis do rejestru przedsiębiorców, złóż stosowny wniosek w sądzie gospodarczym"30. O ile bowiem dyrektywy celowościowe związane z normami promującymi kreują pewien rodzaj premii dla podmiotów realizujących doniosłe

27 K. Opałek, Z teorii dyrektyw i norm, Warszawa 1974, s. 46.

28 Z. Ziembiński, [w:] S. Wronkowska, Z. Ziembiński, Zarys teorii prawa, Poznań 1997, s. 29.

${ }^{29}$ A. Bator, op. cit., s. 80.

30 Ibidem, s. 81. 
społecznie zachowania, o tyle „zwykłe” dyrektywy celowościowe wskazują przeważnie sposób urzeczywistniania przez adresatów dyrektyw ich indywidualnych interesów, indyferentnych z perspektywy interesu społecznego.

\title{
Podsumowanie
}

Metoda promocji należy do dyspozytywnej metody regulacji sensu largo, w ramach której adresatom norm prawnych wskazywane są przez prawodawcę zachowania, które adresaci mogą odrzucić i w sposób zgodny z prawem podjąć zachowania odmienne niż wskazane w normach. Od innych metod szczegółowych w ramach metody regulacji sensu largo metodę promocji wyróżnia ustanowienie przez prawodawcę korzyści z tytułu zastosowania przez adresatów norm promujących zachowań w nich wskazanych. Metoda ta szczególnie szeroko obecna jest w obrębie regulacji prawa gospodarczego. Przy wykorzystaniu norm promujących prawodawca kreuje bodźce zachęty adresowane do przedsiębiorców, nakierowane na skłanianie ich do podejmowania zachowań doniosłych i pożytecznych społecznie. Wydaje się zatem, że zastosowanie metody promocji $\mathrm{w}$ ramach regulacji prawa gospodarczego wynika $\mathrm{z}$ uznania przez prawodawcę różnego rodzaju korzyści (przede wszystkim finansowych) za najskuteczniejszy instrument oddziaływania na przedsiębiorców (kierujących się w swym działaniu dążeniem do maksymalizacji zysku), będącym w stanie najefektywniej skłonić ich — w sposób niewładczy — do zachowań pozytywnie ocenianych z perspektywy wartości chronionych w systemie prawa.

\section{Method of promotion as a type of method of regulation}

\begin{abstract}
Summary
Method of promotion forms a part of the dispositive method of regulation (in a broad sense) which is typical for the method of regulation in the field of economic law. Method of promotion is marked by the benefits that are provided for entrepreneurs who follow patterns of behavior indicated in non-binding promotional norms. The benefits may be of financial nature, consisting of state aid measures and tax exemptions. In the Polish legislation the method of promotion is used to encourage entrepreneurs to conduct innovative activities, employ people with disabilities and participate in the social integration of excluded people.
\end{abstract}

Keywords: method of regulation, method of promotion, economic law, promotional norms, economic benefits. 